\title{
Family food purchases and home food consumption: comparison of nutrient contents
}

\author{
BY M. NELSON*, P. A. DYSON AND A. A. PAUL \\ Medical Research Council, Dunn Nutrition Unit, Milton Road, Cambridge CB4 1XJ
}

(Received 24 October 1984- Accepted 17 April 1985)

\begin{abstract}
1. Estimates of nutrient intakes based on food purchasing records modelled on the National Food Survey (NFS) were compared with nutrient intakes calculated from food consumption records based on a semi-weighed method, a combination of weighing and household measurement techniques. Of eighty-two families in Cambridge who completed the study, thirty-two were volunteers and fifty were from a random sample in which the co-operation rate was $73 \%$.

2. The estimated energy and nutrient contents of the Cambridge food purchases were very similar to those reported by the NFS for families of similar composition and income. The energy intakes obtained by the semi-weighed method were compared with results from twenty-five studies of energy intake based on quantitative measurements of food consumption: there was no evidence to suggest that the semi-weighed method consistently under- or overestimated intakes in the Cambridge subjects.

3. Purchases adjusted to allow for waste and consumption of food by visitors contained significantly more energy, protein, carbohydrate, calcium, iron and dietary fibre than measured home food consumption. There was no significant difference in the nutrient content of purchases and consumption per 4.184 MJ (1000 kcal), with the exception of $\mathrm{Fe}$ and ascorbic acid.

4. Measured wastage of edible food in thirty-one families averaged $3.2 \%$ of purchases. Estimate of wastage in all eighty-two families was $3.8 \%$, and consumption of food by visitors accounted for $3.0 \%$ of purchases.

5. The excess of purchases over measured home food energy intake is probably accounted for by a net increase in larder stocks rather than wastage, consumption of food by visitors, or under-recording of intakes.
\end{abstract}

Studies of food purchases have been used since 1861 to investigate the relations between income, diet and health (Medical Research Council, 1924; Paton \& Findlay, 1926; Cathcart \& Murray, 1931; Orr, 1936; Ministry of Food, 1951, 1952-1954; Ministry of Agriculture, Fisheries and Food, 1955-1983; Barker et al. 1970). Most of the early surveys recorded household food purchases and carried out larder inventories: it was assumed that purchases provided a good estimate of household food consumption after allowing for changes in larder stocks and waste. Unfortunately, the interpretation of the findings was often limited by poor co-operation rates and a distortion of purchasing patterns caused by the larder inventory which drew attention to existing household food stocks (Ministry of Food, 1952-1954). In order to overcome these problems, a new survey without the larder inventory was introduced by the National Food Survey (NFS) in July 1951. It was assumed that if 'the recorded amounts of purchased and free food are averaged over a sufficient time or a large number of households, they should represent - waste apart - what is actually eaten by such households, provided that there is no systematic change in their general level of food stocks' (Derry \& Buss, 1984).

Validation studies showed little change in the energy value of purchases immediately before and after larder inventories were discontinued, with one exception: the energy content of purchases of single female old-age-pensioner (OAP) households was $2.09 \mathrm{MJ}$ $(500 \mathrm{kcal}) /$ person per d greater after inventories ended (Platt et al. 1964). Platt et al. (1964) also examined analyses by Baines \& Hollingsworth (1955) and observed that in this type of household, between April 1953 and March 1954, 'the energy value of food obtained for

* Present address: MRC Environmental Epidemiology Unit, Southampton General Hospital, Southampton SO9 4XY. 
consumption was roughly $1000 \mathrm{kcal} / \mathrm{head}$ daily greater than the recommended requirement'. They concluded that the tendency to build up larder stocks was confined to elderly women living alone. This conclusion, however, was based largely on results obtained during a time when rationing may have substantially limited purchases in other households. No direct comparison of household purchases and consumption has been carried out except in OAP households.

The present paper reports the results of a study designed to test the hypothesis that average food purchases reflect average food consumption: eighty-two Cambridge families with two adults and two or three children recorded food purchases and actual food consumption by household members for 1 week. The method for recording household food purchases was based on that used in the NFS; food consumption was recorded using a quantitative semi-weighed method (Nelson \& Nettleton, 1980).

\section{METHODS}

\section{Sample selection}

Two groups of volunteer families were recruited through local schools and health visitors in 1978. The first group consisted of families from social classes I, II and III manual and non-manual, while the second consisted of large families (up to five children) on low incomes from social classes III manual, IV and V (Office of Population Censuses and Surveys, 1971). A final study in 1979 was based on a random sample of 722 households selected from the electoral register in Cambridge. Following a letter of introduction this sample was screened for households with two adults and two or three children. The range of household composition was restricted in order to provide sufficient information on households of a defined composition.

\section{Purchasing records}

Each family kept a record of food purchases for seven consecutive days. The recording forms and interviewing techniques were modelled on those used in the NFS, who provided formal training for the field-workers in the present study (M.N. and P.A.D.). The food-purchasing records included all foods purchased, plus free food from gardens and allotments, gifts from visitors, and school milk. As in the NFS, alcoholic beverages, sweets and soft drinks were excluded. For the sake of simplicity, the term 'purchases' is used in the present paper to denote all food coming into the house, whether purchased or free, plus school milk, but excluding alcoholic beverages, sweets and soft drinks. The records were coded by the same staff who actually code the NFS.

\section{Food consumption records}

Families kept records of each individual's food consumption over $7 \mathrm{~d}$ concurrent with the purchasing record. The food consumption records were based on a semi-weighed method (Nelson \& Nettleton, 1980), in which total family intakes were weighed, while the intake of each individual was based primarily on household measures, which were quantified for each family. The housewife was also asked to record recipes of home-cooked dishes and the weights of prepared vegetables served to the entire family. The consumption of all food eaten at home and away from home was recorded, including the consumption of alcoholic beverages, soft drinks and sweets.

\section{Comparisons of purchases and food consumption}

The relation between purchases and food consumption was examined in two ways. First, the nutrient content of household food purchases was compared with that of the total measured diet. Secondly, the nutrient contents of purchases and measured diet were 
compared after adjusting the records to take into account the different aspects of diet measured by the two methods. Purchasing information related to the home diet of food only, and food consumption records were edited to exclude food obtained away from home and alcoholic beverages, sweets and soft drinks. Measured consumption related to the food actually consumed by family members only, and the calculated nutrient content of each family's purchases was adjusted by subtracting estimates of the nutrient content of food wasted or given to pets (see 'waste') and of food consumed by visitors. In each household, the proportion of the home diet consumed by visitors $(V)$ was estimated by the NFS staff who coded the purchasing information, from records of the number and type of meals eaten by household members and visitors.

The nutrient content of the purchases was calculated using the NFS food tables (Ministry of Agriculture, Fisheries and Food, unpublished), which are based on McCance and Widdowson's food composition tables (Paul \& Southgate, 1978). Nutrient intakes based on the measured food records were calculated primarily using the computer version of McCance and Widdowson's food composition tables (Paul \& Southgate, 1978), supplemented with calculations from recipes of the nutrient content of an extra eighty-five dishes (Wiles et al. 1980). Analytical values were obtained for a limited number of other foods not listed in the food tables.

\section{Waste}

In the first two studies, families were asked to collect all edible waste, including scrapings from plates and cooking and serving vessels, food which had spoiled, and food intended for human consumption but given to pets (equivalent food was replaced by the investigators). Waste was collected in large plastic boxes with tight-fitting lids, and analysed for protein, fat and carbohydrate after the removal of bones.

Since the amount of waste collected in the first two studies was similar to that reported by Dowler (1977) and Wenlock et al. (1980), families in the random sample were not asked to collect waste, as it was felt that to do so might adversely affect the co-operation rate.

\section{Statistics}

Differences between estimates of nutrient intakes based on purchasing records and measured consumption were assessed for statistical significance using Student's paired $t$ test.

\section{Ethical considerations}

This project was approved by the Ethical Committee of the Dunn Nutrition Unit.

\section{RESULTS}

Sample composition and co-operation

The number of families in the present study is given in Table 1 by household composition and NFS income group (Ministry of Agriculture, Fisheries and Food, 1980). Of the eighty-two families, seventeen were recruited through the schools, fifteen through the health visitors, and fifty through the random sample.

Of the 722 addresses selected from the electoral register, 568 were private households. As in the NFS, only private households were considered to be eligible. There were seventy-four households with two adults and two or three children, of whom fifty-four $(73 \%)$ completed the survey. In two of these fifty-four families an infant was being breast-fed, and in two more the husband was away for more than four nights, and these four families were excluded from the analysis. 
Table 1. The household composition and income group of the eighty-two Cambridge families in which food purchases and measured intakes were compared

\begin{tabular}{lrrrr}
\hline Income group* & $\begin{array}{c}\text { No. of adult... } \\
\text { No. of children... }\end{array}$ & 2 & 3 & $\begin{array}{c}\text { All } \\
\text { households }\end{array}$ \\
\hline A1 & & 4 & 0 & 4 \\
A2 & 4 & 3 & 7 \\
B & 25 & 9 & 34 \\
C & 15 & 11 & 26 \\
D & 5 & 5 & 10 \\
E2 & 1 & 0 & 1 \\
All incomes & 54 & 28 & 82 \\
\hline
\end{tabular}

* For definitions of income groups, see National Food Survey reports for 1978 and 1979 (Ministry of Agriculture, Fisheries and Food, 1980-1981).

Table 2. Average nutrient intakes (/person per d) estimated from eighty-two family food purchase records, and the mean NFS estimates of mutrient consumption per person per day in 1978 , weighted according to the household composition and income groups in the present study

(Mean values with their standard errors)

\begin{tabular}{|c|c|c|c|c|}
\hline \multirow[b]{2}{*}{ Nutrient } & \multicolumn{2}{|c|}{$\begin{array}{l}\text { Estimates of intakes } \\
\text { based on eighty-two household } \\
\text { purchasing records }\end{array}$} & \multicolumn{2}{|c|}{$\begin{array}{l}\text { Weighted NFS } \\
\text { estimate, 1978* }\end{array}$} \\
\hline & Mean & SE & Mean & SE† \\
\hline \multicolumn{5}{|l|}{ Energy } \\
\hline $\mathrm{MJ}$ & $8 \cdot 48$ & 0.40 & $8 \cdot 41$ & $0 \cdot 32$ \\
\hline kcal & 2048 & 94 & 2004 & 78 \\
\hline Protein (g) & $66 \cdot 6$ & $2 \cdot 9$ & $64 \cdot 0$ & $2 \cdot 5$ \\
\hline Fat $(g)$ & $93 \cdot 0$ & $5 \cdot 8$ & $91 \cdot 2$ & $4 \cdot 3$ \\
\hline Carbohydrate (g) & $247 \cdot 1$ & $11 \cdot 5$ & $247 \cdot 0$ & $11 \cdot 6$ \\
\hline Calcium (mg) & 926 & 31 & 908 & 29 \\
\hline $\operatorname{Iron}(\mathrm{mg})$ & $10 \cdot 4$ & 0.4 & $10 \cdot 0$ & 0.4 \\
\hline Retinol equivalents $(\mu \mathrm{g})$ & 1406 & 91 & 1253 & 129 \\
\hline Thiamin (mg) & $1 \cdot 19$ & 0.06 & 1.09 & 0.05 \\
\hline Riboflavin (mg) & $1 \cdot 77$ & 0.06 & $1 \cdot 80$ & 0.07 \\
\hline Nicotinic acid equivalents (mg) & $27 \cdot 4$ & $1 \cdot 3$ & $26 \cdot 2$ & $1 \cdot 1$ \\
\hline Ascorbic acid (mg) & $40 \cdot 8$ & $3 \cdot 0$ & 46.6 & $3 \cdot 3$ \\
\hline
\end{tabular}

NFS, National Food Survey.

* Calculate 8 from the NFS results for 1978 (Ministry of Agriculture, Fisheries and Food, 1980).

$\dagger$ Based on the 1977 NFS estimates of the standard errors (Ministry of Agriculture, Fisheries and Food, 1978).

\section{Reliability}

Before comparing the nutrient content of purchases and measured consumption, it was necessary to ensure that the two sets of results were reliable. This was done by comparing the present results with those from other studies which used similar survey techniques.

Purchases. In Table 2 the nutrient contents of the unadjusted purchases of eighty-two Cambridge families are compared with results from the 1978 NFS (Ministry of Agriculture, Fisheries and Food, 1980). In order to make the Cambridge and NFS results directly comparable, the NFS results were weighted to reflect the composition of the Cambridge sample. The weighted average was obtained by multiplying the reported NFS nutrient 
consumption in each category of household composition and income shown in Table 1 by the number of such households in the Cambridge sample, summing the products over all categories, and dividing by the total number of households in the sample (eighty-two). The standard error was estimated from values given in the 1977 NFS report (Ministry of Agriculture, Fisheries and Food, 1978). There was no statistically significant difference (unpaired two-tailed $t$ test) between the Cambridge and weighted NFS nutrient contents of purchases either as shown in Table 2 or when expressed per MJ,

These findings suggest that the Cambridge survey of food purchases was reliable, in that it followed NFS procedures and produced results very similar to the NFS itself.

Measured consumption. The reliability of the semi-weighed results was assessed by comparing total daily energy intakes by age and sex with results from all the major studies of comparable subjects published in recent years. These studies covered a broad spectrum of age, occupation and social background, and used quantitative prospective methods for recording individual intakes. Fig. 1(a) shows the comparison for males and Fig. $1(b)$ for females. The references, sample details and published values for the letters are given in the Appendix. Where authors did not indicate sex, the reference letters were entered on Fig. $1(a$ and $b) ; 100$ points, including fifteen duplicates, were plotted.

The semi-weighed results are slightly higher than others for boys under 3 years and girls under 2 years of age, and for girls aged 14 or 15 years. The results are slightly lower than others for boys aged 10-14 years, girls aged 16-17 years and for women. Six reference points (indicated by the encircled letters in Fig. 1) were statistically significantly different from the semi-weighed values $(P<0.05$, two-tailed $t$ test). All six reference values were at the extremes of the distribution for their age-group.

There is no suggestion that the semi-weighed method consistently under- or overestimated energy intakes in the Cambridge subjects, and it has been assumed that the nutrient intakes based on the semi-weighed method are as reliable as those based on $7 \mathrm{~d}$ weighed inventories. Further support for this assumption is given by Nelson (1983).

\section{The nutrient content of the total measured diet}

Table 3 shows the average energy and nutrient contents of the Cambridge subjects' total measured diet, including all food, alcoholic beverages, sweets and soft drinks eaten at home or away from home. Although these results are not dissimilar to those given for purchases in Table 2, the two sets of results are not directly comparable: those in Table 3 relate to the total diet, while those in Table 2 relate to the households' purchases of food alone. Both sets of results must be adjusted in order to make a sensible comparison.

\section{The nutrient content of adjusted purchases and home food consumption}

Estimates of average nutrient intakes based on adjusted purchases (AP) and measured home food consumption are compared in Table 4. The values for AP were greater than the mean measured nutrient intakes from food consumed in the home for all nutrients except ascorbic acid, and the differences were significant (paired $t$ test) for all nutrients except fat and four vitamins.

Fig. 2 shows that the relation between the energy value of adjusted purchases and measured home intakes was not close (Pearson's correlation coefficient $r 0 \cdot 22, P<0 \cdot 05$ ). The range of energy content of weekly food purchases was considerably greater than the range of measured intakes, three families having exceptionally large purchases.

Proximate composition. The contribution ( $\%$ ) of protein, fat and carbohydrate to energy was $13 \cdot 1,41 \cdot 3$ and 45.6 for purchases, and $13 \cdot 0,40.4$ and 46.6 for measured intakes respectively. There was no significant difference in proximate composition between purchases and intakes. 

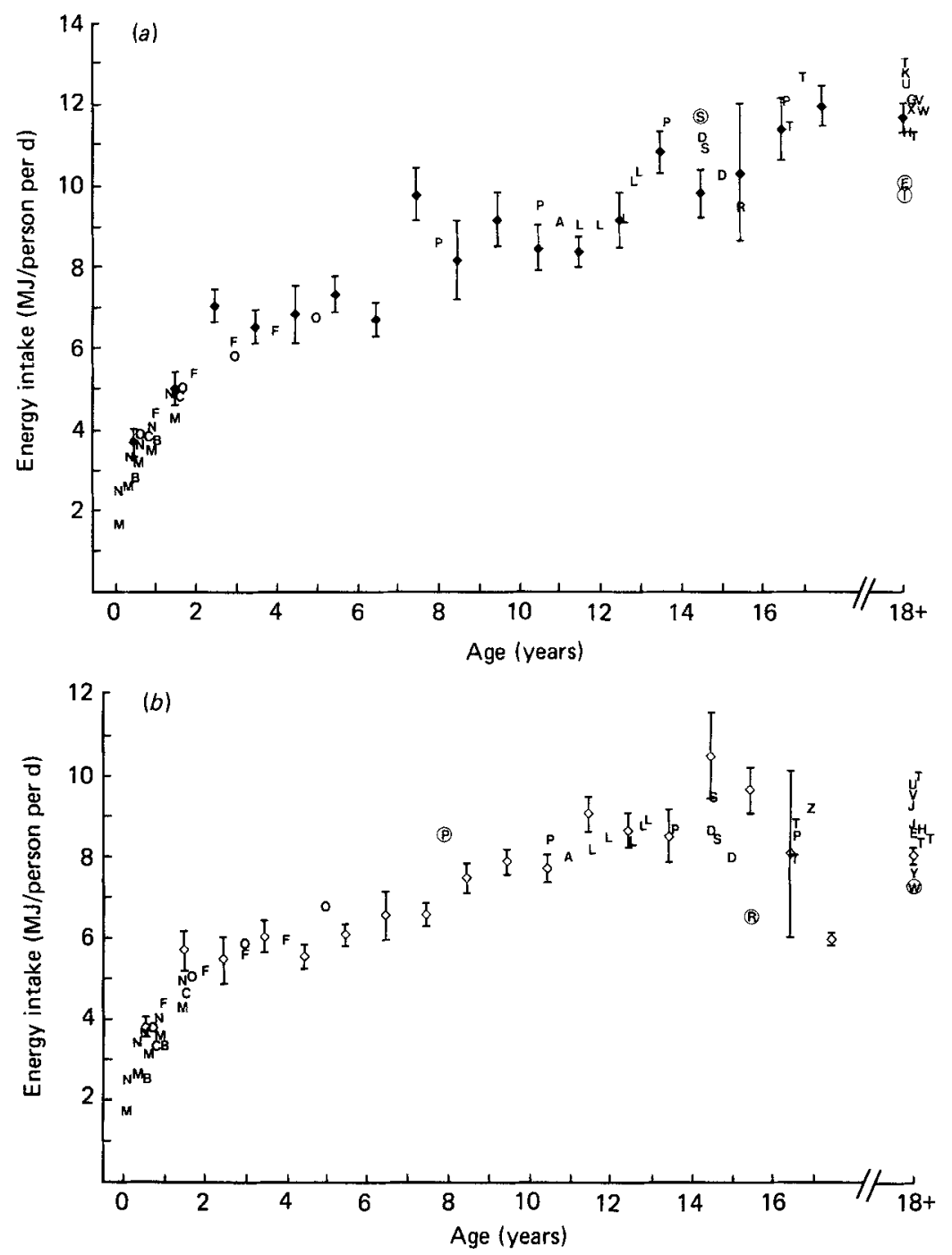

Fig. 1. (a) Mean daily energy intake (MJ/person per d) of 183 Cambridge males aged 0-57 years, by age, and $(b)$ of 173 Cambridge females aged 0-53 years, by age, and values from the literature for comparison (see Appendix for letter values and references). Points are mean values with their standard errors represented by vertical bars. Encircled letter indicates that Cambridge and comparison values were significantly different (unpaired two-tailed $t$ test, $P<0.05$ ). See p. 379 for values for points plotted.

Composition of diet per $4 \cdot 184 \mathrm{MJ}(1000 \mathrm{kcal})$. The nutrient content of purchases and measured home intakes per $4.184 \mathrm{MJ}(1000 \mathrm{kcal})$ is given in Table 5. There was no significant difference in the composition of diet per $4 \cdot 184 \mathrm{MJ}(1000 \mathrm{kcal})$ between purchases and intakes except for iron, ascorbic acid and dietary fibre.

\section{Waste}

Of the eighty-two families in this comparison, thirty-one collected waste. One family did not collect waste as requested, and the remaining fifty families were from the random sample in which waste was not collected. Average measured wastage was $3 \cdot 2 \%$ of food energy 
Fig 1. (cont.) Average daily energy intake (MJ) and sample composition of 356 Cambridge subjects according to age and sex. Values for points plotted in Fig. 1

(Mean values and standard deviations)

\begin{tabular}{|c|c|c|c|c|c|c|}
\hline \multirow{2}{*}{$\begin{array}{c}\text { Age } \\
\text { (years) }\end{array}$} & \multicolumn{3}{|c|}{ Males } & \multicolumn{3}{|c|}{ Females } \\
\hline & Mean & SD & $n$ & Mean & SD & $n$ \\
\hline 0 & 3.69 & 0.82 & 7 & 3.77 & 0.31 & 2 \\
\hline 1 & 5.00 & 1.09 & 7 & 5.68 & 1.19 & 6 \\
\hline 2 & 7.01 & 0.97 & 6 & $5 \cdot 42$ & 1.01 & 3 \\
\hline 3 & 6.53 & $1 \cdot 30$ & 10 & 5.99 & $1 \cdot 15$ & 9 \\
\hline 4 & 6.81 & $1 \cdot 60$ & 7 & $5 \cdot 50$ & 0.66 & 6 \\
\hline 5 & $7 \cdot 30$ & 1.25 & 8 & 6.04 & 0.70 & 8 \\
\hline 6 & 6.65 & 0.85 & 4 & $6 \cdot 55$ & 1.74 & 8 \\
\hline 7 & $9 \cdot 76$ & $1 \cdot 14$ & 3 & $6 \cdot 58$ & 0.47 & 3 \\
\hline 8 & $8 \cdot 20$ & 1.99 & 4 & $7 \cdot 42$ & 0.81 & 5 \\
\hline 9 & $9 \cdot 14$ & 1.78 & 8 & $7 \cdot 84$ & 0.68 & 5 \\
\hline 10 & 8.48 & $1 \cdot 50$ & 8 & $7 \cdot 70$ & 1.03 & 10 \\
\hline 11 & $8 \cdot 38$ & 0.67 & 4 & 8.94 & 1.18 & 8 \\
\hline 12 & $9 \cdot 17$ & 1.22 & 3 & 8.60 & 0.82 & 4 \\
\hline 13 & 10.80 & 1.01 & 4 & $8 \cdot 48$ & 1.38 & 4 \\
\hline 14 & $9 \cdot 79$ & 1.46 & 7 & $10 \cdot 51$ & 1.84 & 3 \\
\hline 15 & $10 \cdot 27$ & 2.91 & 3 & 9.66 & $1 \cdot 10$ & 4 \\
\hline 16 & 11.39 & $1 \cdot 34$ & 3 & 8.09 & 2.90 & 2 \\
\hline 17 & 11.93 & 1.05 & 5 & 5.99 & - & 1 \\
\hline $18+$ & 11.61 & 3.06 & 82 & $8 \cdot 01$ & 1.85 & 82 \\
\hline All ages & - & - & 183 & - & - & 173 \\
\hline
\end{tabular}

Table 3. Average nutrient intakes (/person per d) including all food, alcoholic beverages, sweets and soft drinks eaten at home or away from home in eighty-two Cambridge families (Mean values with their standard errors)

\begin{tabular}{lcc}
\hline & \multicolumn{2}{c}{ Average daily intake } \\
\cline { 3 - 3 } \multicolumn{1}{c}{ Nutrient } & Mean & se \\
\hline Energy & & \\
MJ & $8 \cdot 58$ & $0 \cdot 16$ \\
kcal & 2051 & 39 \\
Protein (g) & $64 \cdot 4$ & $1 \cdot 3$ \\
Fat (g) & $90 \cdot 0$ & $2 \cdot 0$ \\
Carbohydrate (g) & $250 \cdot 8$ & $5 \cdot 1$ \\
Calcium (mg) & 901 & 24 \\
Iron (mg) & $10 \cdot 2$ & $0 \cdot 2$ \\
Retinol equivalents $(\mu \mathrm{g})$ & 1366 & 96 \\
Thiamin (mg) & $1 \cdot 08$ & $0 \cdot 03$ \\
Riboflavin (mg) & $1 \cdot 78$ & $0 \cdot 05$ \\
Nicotinic acid equivalents (mg) & 27.6 & $0 \cdot 6$ \\
Ascorbic acid (mg) & $45 \cdot 7$ & $2 \cdot 1$ \\
Dietary fibre (g) & $14 \cdot 0$ & $0 \cdot 4$ \\
\hline
\end{tabular}

purchased. The contribution (\%) of protein, fat and carbohydrate to the energy in waste was $11.5,53.2$ and 35.3 respectively. Waste had proportionately more fat and less protein and carbohydrate than the food purchases. However, when the nutrient content of purchases was adjusted to allow for waste, the wastage of all nutrients was taken to be in 
Table 4. Average nutrient intakes $\dagger$ (/person per $d$ ) estimated from adjusted purchase records $\ddagger$ and measured home food consumption in eighty-two Cambridge families

(Mean values with their standard errors)

\begin{tabular}{|c|c|c|c|c|c|}
\hline \multirow[b]{2}{*}{ Nutrient } & \multicolumn{2}{|c|}{$\begin{array}{l}\text { Intakes estimated } \\
\text { from adjusted } \\
\text { purchases }{ }^{\ddagger}\end{array}$} & \multicolumn{2}{|c|}{$\begin{array}{l}\text { Measured home } \\
\text { intakes } \dagger\end{array}$} & \multirow{2}{*}{$\begin{array}{l}\text { Percentage } \\
\text { difference§ }\end{array}$} \\
\hline & Mean & SE & Mean & $\mathrm{SE}$ & \\
\hline \multicolumn{6}{|l|}{ Energy } \\
\hline $\mathrm{MJ}$ & $7 \cdot 95$ & $0 \cdot 37$ & 6.91 & $0 \cdot 16$ & $15^{*}$ \\
\hline kcal & 1919 & 90 & 1646 & 38 & $15^{*}$ \\
\hline Protein $(\mathrm{g})$ & $62 \cdot 3$ & $2 \cdot 8$ & $54 \cdot 2$ & $1 \cdot 2$ & $15^{* *}$ \\
\hline Fat (g) & $86 \cdot 3$ & $5 \cdot 6$ & $75 \cdot 2$ & $1 \cdot 9$ & 15 \\
\hline Carbohydrate (g) & 232 & 11 & 200 & 5 & $16^{*}$ \\
\hline Calcium (mg) & 862 & 30 & 744 & 24 & $16^{* *}$ \\
\hline Iron $(\mathrm{mg})$ & $9 \cdot 7$ & 0.4 & $8 \cdot 7$ & 0.2 & $14^{*}$ \\
\hline Retinol equivalents $(\mu \mathrm{g})$ & 1300 & 133 & 1194 & 96 & 9 \\
\hline Thiamin (mg) & $1 \cdot 12$ & 0.06 & 0.94 & $0 \cdot 03$ & $19^{* *}$ \\
\hline Riboflavin (mg) & 1.65 & 0.06 & $1 \cdot 53$ & 0.05 & 9 \\
\hline Nicotinic acid equivalents (mg) & $25 \cdot 7$ & $1 \cdot 1$ & $23 \cdot 2$ & $0 \cdot 6$ & 11 \\
\hline Ascorbic acid (mg) & $38 \cdot 2$ & $2 \cdot 8$ & $39 \cdot 6$ & $2 \cdot 1$ & -4 \\
\hline Dietary fibre $(\mathrm{g})$ & $18 \cdot 2$ & $1 \cdot 0$ & $12 \cdot 4$ & 0.5 & $47^{* * *}$ \\
\hline
\end{tabular}

Significance of differences between intakes estimated from purchases and measured home intakes (paired $t$ test): ${ }^{*} P<0.02,{ }^{* *} P<0 \cdot 01,{ }^{* * *} P<0.001$.

+ Excluding alcoholic beverages, sweets and soft drinks.

* Adjusted for waste and the presence of visitors at meals.

$\S \frac{\text { Adjusted purchases }- \text { intakes }}{\text { intakes }} \times 100$.

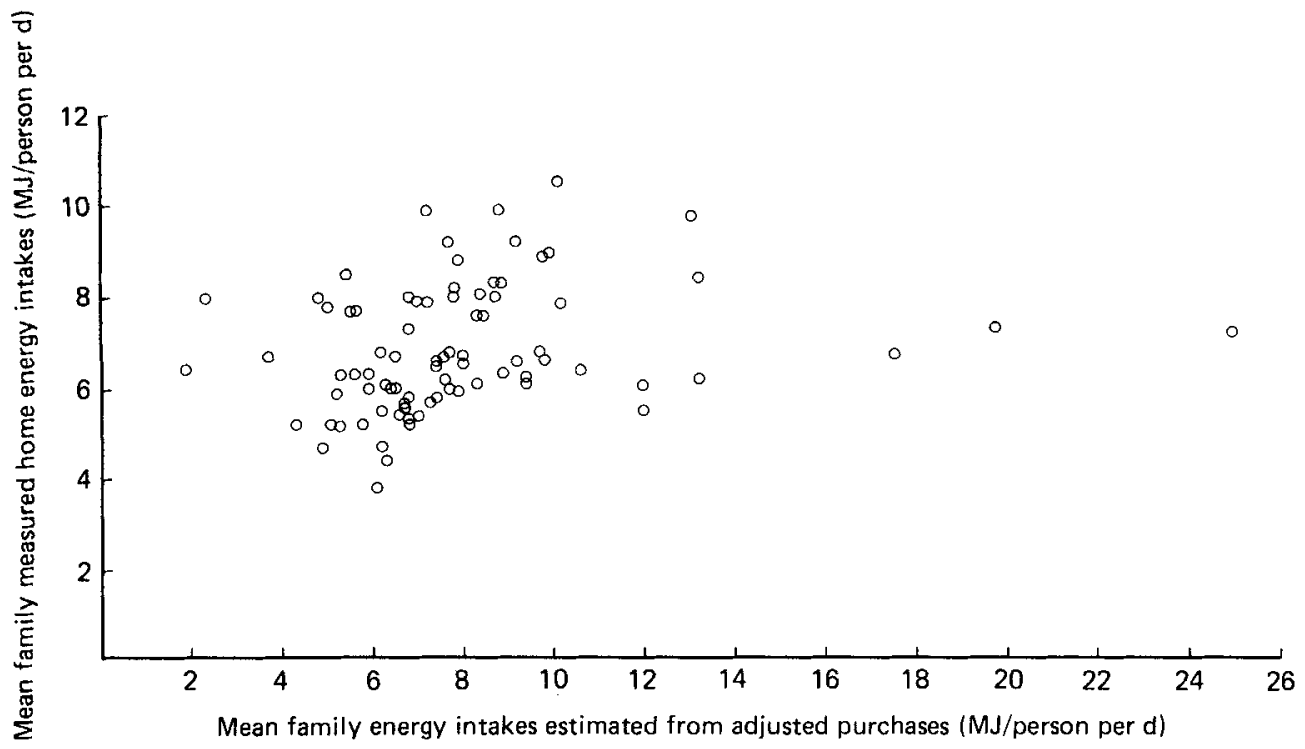

Fig. 2. Relation between the energy contents of measured home food consumption (excluding alcoholic beverages, sweets and soft drinks) and food purchases (adjusted for waste and visitors' food consumption) in eighty-two Cambridge families; $r 0.22, P<0.05$. 
Table 5. The nutrient content (per 4.184 MJ (1000 kcal)) of purchases and measured home food consumption in eighty-two Cambridge families

(Mean values with their standard errors)

\begin{tabular}{|c|c|c|c|c|}
\hline \multirow[b]{2}{*}{ Nutrient } & \multicolumn{2}{|c|}{ Purchases } & \multicolumn{2}{|c|}{$\begin{array}{l}\text { Measured home } \\
\text { intakes } \dagger\end{array}$} \\
\hline & Mean & SE & Mean & $\mathrm{SE}$ \\
\hline Protein $(\mathrm{g})$ & $33 \cdot 3$ & 0.6 & $32 \cdot 9$ & $0 \cdot 3$ \\
\hline Fat $(g)$ & 44.7 & 0.9 & $45 \cdot 7$ & 0.5 \\
\hline Carbohydrate (g) & $121 \cdot 5$ & $2 \cdot 5$ & $121 \cdot 5$ & $1 \cdot 1$ \\
\hline Calcium (g) & 483 & 17 & 452 & 14 \\
\hline Iron (mg) & $5 \cdot 1$ & $0 \cdot 1$ & $5 \cdot 3^{*}$ & $0 \cdot 1$ \\
\hline Retinol equivalents $(\mu \mathrm{g})$ & 739 & 86 & 725 & 62 \\
\hline Thiamin (mg) & 0.59 & $0 \cdot 02$ & 0.57 & 0.01 \\
\hline Riboflavin (mg) & 0.90 & $0 \cdot 03$ & 0.93 & 0.02 \\
\hline Nicotinic acid equivalents (mg) & $13 \cdot 5$ & $0 \cdot 3$ & $14 \cdot 1$ & $0 \cdot 2$ \\
\hline Ascorbic acid (mg) & $19 \cdot 9$ & $1 \cdot 1$ & $23 \cdot 2^{*}$ & $1 \cdot 3$ \\
\hline Dietary fibre $(\mathrm{g})$ & $9 \cdot 6$ & $0 \cdot 3$ & $7 \cdot 5^{*}$ & $0 \cdot 2$ \\
\hline
\end{tabular}

Significance of differences between purchases and measured home intakes (paired $t$ test): ${ }^{*} P<0 \cdot 05$.

$\dagger$ Excluding alcoholic beverages, sweets and soft drinks.

proportion to the wastage of energy, as the changes in AP for the proximates were negligible when the measured proximate values for waste were substituted, and no result was obtained concerning the wastage of other nutrients. Wherever possible, the value for wastage specific to each family was used to calculate AP. Where no specific value was available, waste was estimated to be $4.9 \%$ for families with two adults and two children, and $4.0 \%$ for families with two adults and three children. These values were based on those from the present study plus results from Dowler (1977), Wenlock \& Buss (1977) and Wenlock et al. (1980). The average wastage in the eighty-two households was estimated to be $3.8 \%$.

\section{Visitors' consumption of food}

The NFS coders estimated that food eaten by visitors at meal times accounted on average for just under $3 \%$ of the families' home food consumption, ranging from $0 \%$ to $16 \%$. Each family's specific estimate for $V$ was used when calculating AP. The value for $V$ was based only on the number and type of meals eaten, and did not take into account visitors' consumption of snacks or beverages between meals. These foods (including milk and sugar in tea and coffee) accounted on average for not more than $0.628 \mathrm{MJ}(150 \mathrm{~kJ}) /$ family per $\mathrm{d}$, less than $0.5 \%$ of average family food energy purchased.

\section{DISCUSSION}

\section{Sample co-operation}

The co-operation rate of $73 \%$ in the random sample compares favourably with other surveys (Bransby \& Wagner, 1945; Marr, 1971; United States Department of Health, Education and Welfare, 1972; Department of Health and Social Security, 1975; National Center for Health Statistics, 1977). This co-operation rate is based on the premise that all eligible families, i.e. those selected from the electoral register with two adults and two or three children, were contacted. This is highly likely as: (1) the screening was done at times when families with children were most likely to be at home; (2) information on household composition was usually obtained even if no further questions were answered; (3) the 
proportion of the sample of private households containing two adults and two or three children $(13 \%)$ was equal to that obtained from census data collected in Cambridge in 1977 (Waley, 1978).

\section{Relating purchases to home food intakes}

On average, family purchases of food contained more energy and nutrients than did the food eaten at home during the survey week, even after allowing for waste and visitors' consumption of food. No conclusive evidence can be offered to explain the discrepancy, but if one accepts that the measured food intake was a reliable estimate of the family's actual food consumption and allows for possible imprecision in measuring waste and the amount of food consumed by visitors (see below), then the only explanation remaining is that foods must have been purchased in excess of needs during the survey week.

1. Overpurchasing. The very act of being surveyed may have stimulated extra purchasing during the week, as was shown to occur in NFS households containing elderly women living alone (Platt et al. 1964). Purchases made in bulk or stimulated by special offers and discounts plus the need to avoid running out of non-perishables may mean that a surplus is often purchased for the larder. This, coupled with the fact that many foods are available in large packets of more than 1 week's supply may frequently result in a positive food balance within a household.

Because of the complexity of use of flour, sugar, fats and other such items, it was not possible to quantify accurately overpurchasing of specific foodstuffs. Results in Table 4 suggest that the overpurchasing was occurring throughout the range of foods purchased, as the differences between purchases and intakes were consistent for all nutrients, except for ascorbic acid and dietary fibre. (This inconsistency is due to food composition values, see p. 383.) The similarity of proximate composition and nutrients per $4.184 \mathrm{MJ}(1000 \mathrm{kcal})$ between purchases and intakes (Table 5) offers further evidence that overpurchasing was a general phenomenon and not restricted to certain foodstuffs.

2. Reduced food consumption. Although the present results showed good agreement with other recent quantitative studies of food energy intake (Fig. 1), it is possible that the time-consuming task of recording food intake could have resulted in an underestimate of nutrient intake, both in this and numerous other studies. A more valid test of reliability of the measured intakes would only be obtained by independent means such as measurements of energy expenditure, maintenance of body-weight in adults or the use of biological markers.

In the present study, a few housewives thought that they had simplified the diet during the week in order to make recording easier, but none thought that the actual level of food consumption had been reduced. Virtually all housewives stated that the very diversity of eating habits and demands within the family made it difficult to deviate from normal patterns of eating.

During the survey week, one man was ill for $2 \mathrm{~d}$, and two men and three women were on a diet to lose weight, so the average intakes in these families were below what they might have been normally. However, respondents stated that purchases were adjusted to take into account the altered eating habits. Excluding these six families from the analysis did not alter the basic conclusions of the study.

3. Reduction in food wasted. The factor for waste was, in all likelihood, an underestimate. It is virtually impossible to collect waste without drawing respondents' attention to it. However, even if waste were subconsciously reduced by, say, $25 \%$ this would have accounted for no more than an additional $1 \%$ of the average family's total purchases.

4. Food consumption by visitors. The estimate of the amount of food given to visitors was possibly too low, as it referred to meals only and did not include snacks. The average 
additional consumption of snacks and milk and sugar in beverages by visitors was at most about $0.5 \%$ of average purchases.

5. Food composition values. Some of the differences between the purchases and measured intakes of ascorbic acid and dietary fibre were due to differences in the food tables used to calculate the two sets of values. The estimates of ascorbic acid purchased were based mainly on raw food values adjusted to allow for cooking losses. Because these allowances were greater than the cooking losses reported by Paul \& Southgate (1978), the values for ascorbic acid purchased were low in relation to measured intakes. Dietary fibre values for purchases were based on separate values for raw foods (S. Bingham, personal communication). The raw-food values are, on the whole, higher than the values for cooked foods given by Paul \& Southgate (1978). There was insufficient information to adjust the value of dietary fibre purchased to allow for changes in fibre on cooking.

The idea that average household purchases should reflect average intakes is based on the assumption that there is no systematic change in the level of food stocks. This might be so if one family measured purchases over fifty-two consecutive weeks: average net storage per week would probably be very close to zero. However, if fifty-two families measured purchases for 1 week, each family would be free to store (or remove from store) unspecified quantities of food, independent of the amounts actually consumed. There is no a priori reason why net storage should be zero, and therefore no constraint on the relation between purchases and intakes.

It is not known how many households, or what length of measurement period would be required in order to minimize the discrepancy demonstrated in the present study of eighty-two households, but it would be reasonable to assume that it would be less likely to be present in the large sample size, 7500 households annually, taken by the NFS.

However, for many years the Ministry of Agriculture, Fisheries and Food has been unable to explain why the national estimates of food energy available exceed the theoretical energy requirements of the population (Ministry of Agriculture, Fisheries and Food, 1963). For example, in 1978 the average energy content of the household diet in England, Scotland and Wales was estimated to be $9.46 \mathrm{MJ}(2260 \mathrm{kcal}) /$ person per d (Ministry of Agriculture, Fisheries and Food, 1980). The Ministry of Agriculture, Fisheries and Food estimated that $89 \%$ of total food energy intake was obtained from the household diet and, in theory, food eaten away from home accounted for the remaining $11 \%$, equivalent to $1.17 \mathrm{MJ}$ $(279 \mathrm{kcal}) /$ person per $\mathrm{d}$. The NFS values do not include energy from alcoholic beverages, sweets and soft drinks, which together were estimated to provide a further $1.40 \mathrm{MJ}$ (335 kcal)/person per d nationally (Ministry of Agriculture, Fisheries and Food, 1980). The sum of the total energy available thus calculated is $12.02 \mathrm{MJ}(2874 \mathrm{kcal}) /$ person per $\mathrm{d}$. This estimate is $2.48 \mathrm{MJ}(593 \mathrm{kcal})$ in excess of the average energy requirement of the population, $9.54 \mathrm{MJ}(2280 \mathrm{kcal}) /$ person per $\mathrm{d}$, calculated from the estimated energy requirements of forty age-sex categories (Department of Health and Social Security, 1979) and the number of people in each category (Central Statistical Office, 1979). If the degree of overpurchasing observed in the present study is extrapolated to the NFS as an illustration, then food energy purchased would exceed actual consumption by about $13 \%$ of $9.46 \mathrm{MJ}(2260 \mathrm{kcal})$ or 1.23 MJ $(294 \mathrm{kcal}) / \mathrm{d}$. This would account for half the $2.48 \mathrm{MJ}(593 \mathrm{kcal})$ difference quoted previously. The remaining half could be accounted for by waste $(6 \%$ of purchases (Wenlock et al. 1980)), consumption of food by visitors ( $4 \%$, Ministry of Agriculture, Fisheries and Food, 1980), and errors in estimating nutrient intake away from home, consumption of sweets, soft drinks and alcoholic beverages, and the population energy requirement.

The differences demonstrated between measured home nutrient intakes and intakes estimated from purchases call for careful interpretation and use of the results from 
purchasing surveys such as the NFS. Some of the strengths and weaknesses of the NFS have been outlined in a recent paper (Derry \& Buss, 1984). Epidemilogical studies making use of NFS results to estimate intakes of particular nutrients (Bingham et al. 1979) or foods (Knox, 1972; Shaper \& Marr, 1977; Marmot et al. 1978) have assessed time trends or geographical variations in family purchases, but the relation of these to actual intakes may vary according to purchasing habits in different years, income groups, family types and regions.

The authors thank the Ministry of Agriculture, Fisheries and Food for their financial support; Dr D. A. T. Southgate for his help and advice; Mr C. M. J. Dutton and Mr K. C. Day for computing expertise; Mrs Sheila Levitt for punching the data; Mrs M. J. Harper of the Dunn Nutrition Unit and Mr R. E. Moxon of the Laboratory of the Goverriment Chemist for analysis of foods; Mrs J. Taylor of the British Market Research Bureau for coding the purchasing data. The authors give special thanks to all the families who worked so hard completing the surveys. They are also indebted to Mrs Hetty Linden and Miss Ina Klingenberg for their help in the third study.

The views expressed in this paper are those of the authors and do not necessary reflect those of the Ministry of Agriculture, Fisheries and Food.

\section{REFERENCES}

Baines, A. H. J. \& Hollingsworth, D. F. (1955). Proceedings of the Nutrition Society 14, 77-80.

Barker, T. C., Oddy, D. J. \& Yudkin, J. (1970). Occasional Paper no. 1. London: Queen Elizabeth College, University of London.

Bingham, S., McNeil, N. I. \& Cummings, J. H. (1981). British Journal of Nutrition 45, 23-36.

Bingham, S., Williams, D. R. R., Cole, T. J. \& James, W. P. T. (1979). British Journal of Cancer $40,456-463$.

Black, A. E., Billewicz, W. Z. \& Thomson, A. M. (1976). British Journal of Nutrition 35, 105-113.

Bransby, E. R. \& Wagner, G. (1945). British Medical Journal ii, 682-685.

Bull, N. L., Smart, G. \& Judson, H. (1983). Proceedings of the Nutrition Society 42, 15 A.

Cathcart, E. P. \& Murray, A. M. T. (1931). Medical Research Council Special Report Series no. 151. London: H.M. Stationery Office.

Central Statistical Office (1979). Social Trends no. 10. London: H.M. Stationery Office.

Cook, J., Altman, D. G., Moore, D. M. C., Topp, S. G. \& Holland, W. W. (1973). British Journal of Preventive and Social Medicine 27, 91-99.

Darke, S. J., Disselduff, M. M. \& Try, G. P. (1980). British Journal of Nutrition 44, 243-252.

Department of Health and Social Security (1975). Report on Health and Social Subjects no. 10. London: H.M. Stationery Office.

Department of Health and Social Security (1979). Report on Health and Social Subjects no. 15. London: H.M. Stationery Office.

Department of Health and Social Security (1981). Report on Health and Social Subjects no. 21. London: H.M. Stationery Office.

Derry, B. J. \& Buss, D. H. (1984). British Medical Journal 288, 765-767.

Dowler, E. A. (1977). Journal of Human Nutrition 31, 171-180.

Durnin, J. V. G. A., Blake, E. C. \& Brockway, J. M. (1957). British Journal of Nutrition 11, 85-94.

Durnin, J. V. G. A., Lonergan, M. E., Good, J. \& Ewan, A. (1974). British Journal of Nutrition 32, $169-179$.

Fletcher, J., James, J. \& Coghill, N. F. (1972). Nutrition (London) 29, 25-32.

Garry, R. C., Passmore, R., Warnock, G. M. \& Durnin, J. V. G. A. (1955). Medical Research Council Special Report Series no. 289. London: H.M. Stationery Office.

Gibson, R. S. \& Scythes, C. A. (1982). British Journal of Nutrition 48, 241-248.

Hackett, A. F., Rugg-Gunn, A. J., Appleton, D. R. \& Eastoe, J. E. (1982). Proceedings of the Nutrition Society 41, $144 \mathrm{~A}$.

Hagger, D. L. (1975). Proceedings of the Nutrition Society 34, 119A.

Knox, E. G. (1972). British Journal of Preventive and Social Medicine 26, 219-223.

Lacey, J. H., Chadbund, C., Crisp, A. H., Whitehead, J. \& Stordy, J. (1978). Journal of Human Nutrition 32, $419-426$.

McKillop, F. M. \& Durnin, J. V. G. A. (1982). Human Nutrition: Applied Nutrition 36A, 405-421.

McNaughton, J. W. \& Cahn, A. J. (1970). British Journal of Nutrition 24, 331-344.

Marmot, M. G., Adelstein, A. M., Robinson, N. \& Rose, G. A. (1978). British Medical Journal ii, $1109-1112$.

Marr, J. W. (1971). World Review of Nutrition and Dietetics 13, 105-164. 
Marr, J. W. (1973). Health Trends 5, 37-39.

Medical Rescarch Council (1924). Medical Research Council Special Report Series no. 87. London: H.M. Stationery Office.

Ministry of Agriculture, Fisheries and Food (1955-1983). Household Food Consumption and Expenditure. Annual reports for the years 1953-1981. London: H.M. Stationery Office.

Ministry of Food (1951). The Urban Working-class Household Diet 1940-1949. London: H.M. Stationery Office.

Ministry of Food (1952-1954). Domestic Food Consumption and Expenditure: 1950-1952. London: H.M. Stationery Office.

Morgan, J. \& Mumford, P. (1977). Proceedings of the Nutrition Society 36, 47A.

Morgan, J., Mumford, P. \& Evans, E. (1976). Proceedings of the Nutrition Society 35, 74 A-75 A.

National Center for Heaith Statistics (1977). Heaith and Nutrition Examination Survey. Advancedata HRA 77-1250 no. 6. Rockville, Md: US Department of Health, Education and Welfare.

Nelson, M. (1983). A dietary survey method for measuring family food purchases and individual nutrient intakes concurrently, and its use in dietary surveillance. PhD Thesis, University of London.

Nelson, M. \& Nettleton, P. A. (1980). Journal of Human Nutrition 34, 325-348.

Office of Population Censuses and Surveys (1971). Classification of Occupations. London: H.M. Stationery Office.

Orr, J. B. (1936). Food, Health and Income, Report on a Survey of Adequacy of Diet in Relation to Income. London: Macmillan.

Paton, D. N. \& Findlay, L. (1926). Medical Research Council Special Report Series no. 101. London: H.M. Stationery Office.

Paul, A. A. \& Southgate, D. A. T. (1978). McCance and Widdowson's The Composition of Foods. London: H.M. Stationery Office.

Platt, B. S., Gray, P. G., Parr, E., Baines, A. H. J., Clayton, S., Hobson, E. A., Hollingsworth, D. F., Berry, W. T. C. \& Washington, E. (1964). British Journal of Nutrition 18, 413429.

Ruck, N. (1974). Proceedings of the Nutrition Society 33, 17A-18A.

Shaper, A. G. \& Marr, J. W. (1977). British Medical Journal i, 867-871.

Stordy, B. J. (1972). Proceedings of the Nutrition Society 31, 81 A-83 A.

Thomson, M., Logan, R. L., Sharman, M., Lockerbie, L., Riemersma, R. A. \& Oliver, M. F. (1982). Human Nutrition: Applied Nutrition 36A, 272-280.

United States Department of Health, Education and Welfare (1972). Ten-State Nutrition Survey 1968-1970. DHEW Publication no. (HMS) 72-8130.

Waley, S. (1978). Private Household and Institutional Population Tables. Cambridge: Cambridgeshire County Planning Department.

Wenlock, R. W. \& Buss, D. H. (1977). Journal of Human Nutrition 31, 405-411.

Wenlock, R. W., Buss, D. H., Derry, B. J. \& Dixon, E. J. (1980). British Journal of Nutrition 43, 53-70.

Whitehead, R. G., Paul, A. A. \& Cole, T. J. (1981). Journal of Human Nutrition 35, 339-348.

Wiles, S. J., Nettleton, P. A., Black, A. E. \& Paul, A. A. (1980). Journal of Human Nutrition 34, $189-223$.

Yarnell, J. W. G., Fehily, A. M., Milbank, J. E., Sweetnam, P. M. \& Walker, C. L. (1983). Human Nutrition: Applied Nutrition 37A, 103-112. 


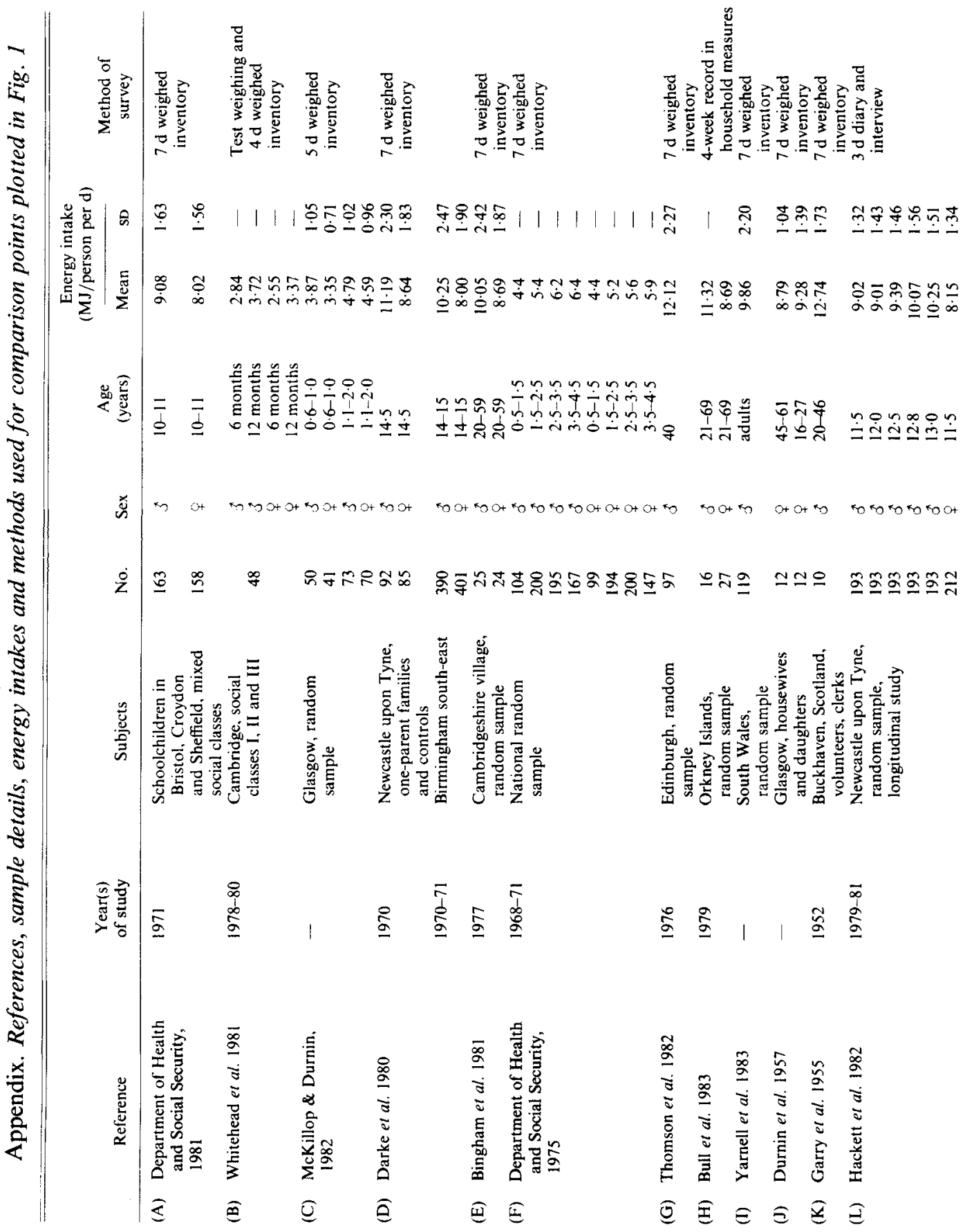




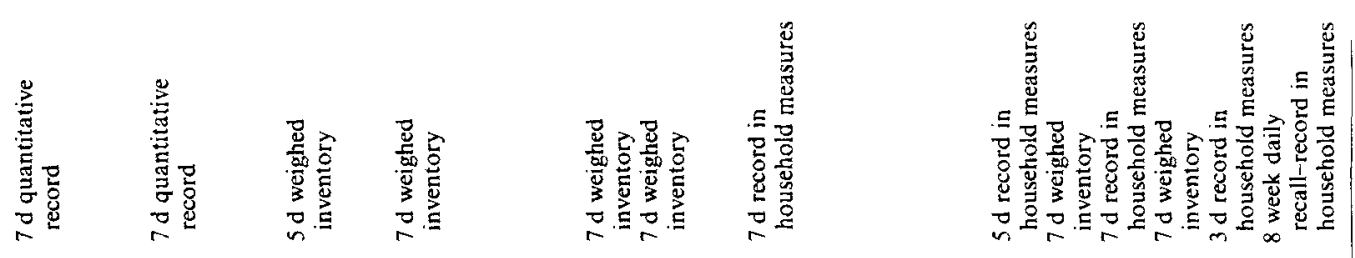

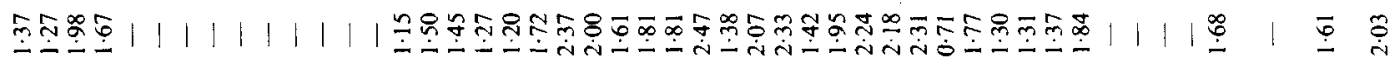

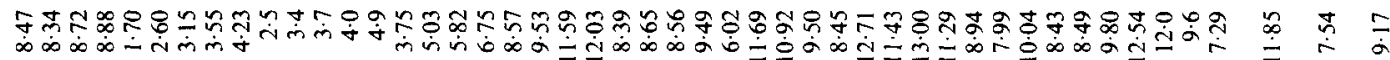

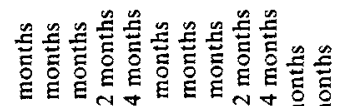

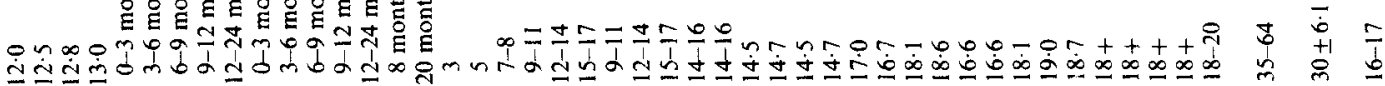

The

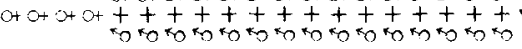

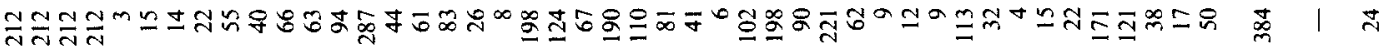

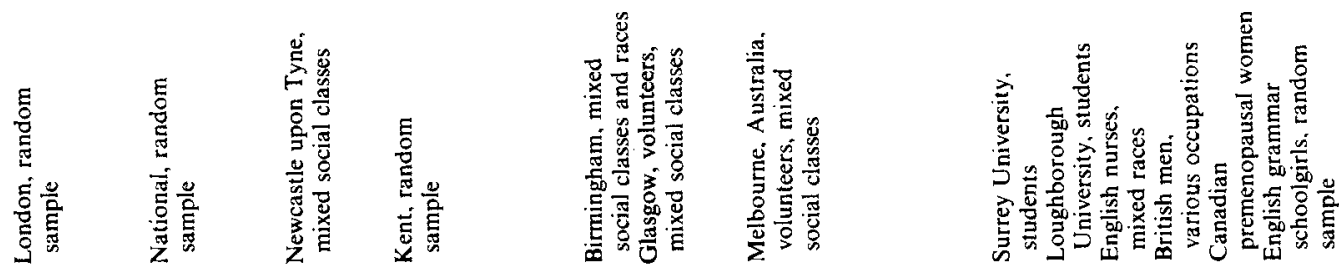

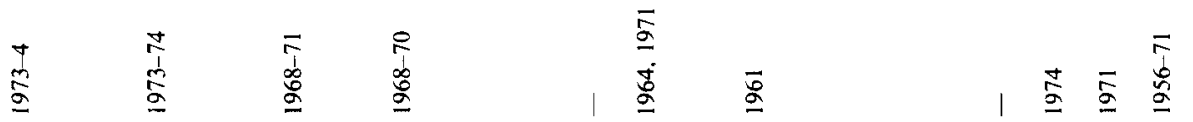

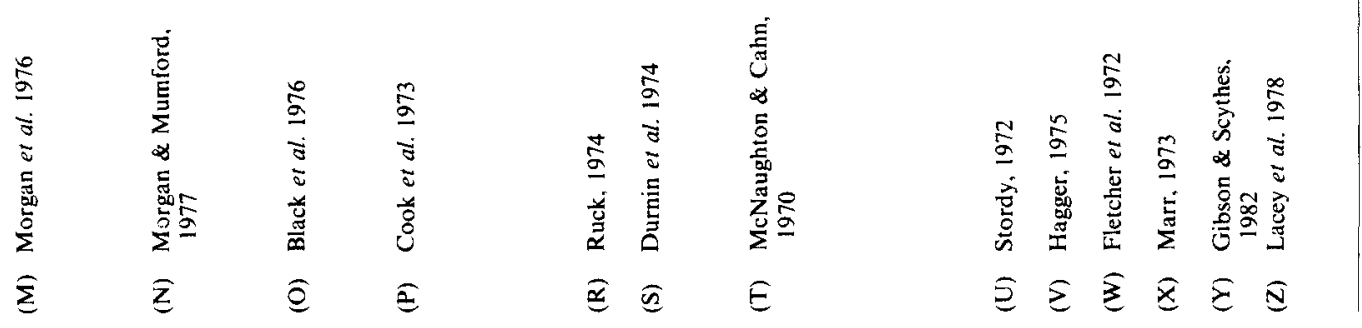

